\title{
Field Evaluation of Newly-Developed Controlled Release Fertilizer on Rice Production and Nitrogen Uptake
}

(Penilaian Lapangan Terhadap Baja Perlepasan Terkawal ke atas Penghasilan Padi dan Pengambilan Nitrogen)

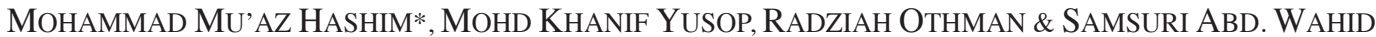

\begin{abstract}
Implementation of sound fertilizer management in rice cultivation is essential in optimizing productivity and profitability. The use of controlled release fertilizer (CRF) to improve crop production in various cropping systems has been widely explored, with new approaches and materials continually being studied to produce new CRF. A field study was carried out to determine the efficiency of local CRFs on rice production and $N$ uptake using MR220 CL1 rice variety. Ten different types of CRFs consisting of two groups namely biochar impregnated urea (BIU 300-5, BIU 300-10, BIU 700-5 and BIU 700-10) and palm stearin (PS) coated urea with nitrification inhibitors (PS, PS+DMPP-100, PS+DMPP-50, PS+DMPP-150, $P S+C u$ and $P S+Z n)$ were used as treatments. Plant height, SPAD reading, 1000-grain weight and harvest index (HI) showed significant improvement in rice treated with both biochar impregnated and palm stearin coated urea. With respect to grain yield, BIU 300-10, BIU 700-5, BIU 700-10, PS+DMPP-100, PS+DMPP-50, PS+DMPP-150 and PS+Cu treatments significantly increased rice yield. The CRFs mostly showed significantly higher $N$ uptake in rice, especially in rice grains, however, there was no significant difference among treatments in soil residual ammonium $\left(\mathrm{NH}_{4}^{+}-\mathrm{N}\right)$. The newly-developed CRFs showed huge potential as an alternative for common urea, especially BIU 700-5, BIU 700-10, PS+DMPP-100 and PS+DMPP-50, in increasing rice grain yield. With proper approaches, these CRFs can contribute in improving rice production to provide sufficient food for ever increasing population.
\end{abstract}

Keywords: Biochar impregnated urea; efficiency; nitrification inhibitors; palm stearin; urea

\section{ABSTRAK}

Pengurusan pembajaan yang baik untuk penanaman padi adalah penting dalam meningkatkan pengeluaran dan keuntungan. Penggunaan baja perlepasan terkawal untuk meningkatkan pengeluaran tanaman telah dikaji secara meluas dan pelbagai pendekatan baru digunakan untuk menghasilkan baja yang terkini. Sebuah kajian lapangan telah dijalankan untuk menentukan keberkesanan baja perlepasan terkawal yang dihasilkan secara tempatan ke atas pengeluaran padi dan pengambilan $N$ dengan menggunakan varieti padi MR220 CL1. Sepuluh jenis baja telah digunakan dalam kajian ini yang terdiri daripada dua kumpulan, iaitu urea diimpregnasi dengan biochar (BIU 300-5, BIU 300-10, BIU 700-5 dan BIU 700-10) dan urea bersalut stearin sawit dengan penghalang nitrifikasi (PS, PS+DMPP-100, PS+DMPP-50, $P S+D M P P-150, P S+C u$ dan $P S+Z n$ ). Ketinggian pokok, bacaan SPAD, berat 1000 biji padi dan indeks tuaian menunjukkan peningkatan yang signifikan untuk padi yang dirawat menggunakan baja urea diimpregnasi dengan biochar dan urea bersalut stearin sawit. Penggunaan baja BIU 300-10, BIU 700-5, BIU 700-10, PS+DMPP-100, PS+DMPP-50, PS+DMPP-150 dan $P S+C u$ telah meningkatkan penghasilan padi dengan signifikan. Penggunaan baja perlepasan terkawal juga meningkatkan pengambilan $N$ oleh pokok padi terutamanya dalam biji padi. Walau bagaimanapun, tiada kesan dapat diperhatikan untuk baki ammonium $\left(\mathrm{NH}_{4}^{+}-\mathrm{N}\right)$ dalam tanah. Baja perlepasan terkawal yang baru ini dilihat berpotensi besar bagi menggantikan baja urea dalam meningkatkan hasil padi, terutamanya BIU 700-5, BIU 700-10, PS+DMPP-100 dan PS+DMPP-50. Dengan pendekatan yang bersesuaian, baja perlepasan terkawal ini mampu menyumbang kepada peningkatan hasil padi negara, seterusnya menyediakan bekalan makanan yang mencukupi untuk menampung jumlah penduduk yang semakin bertambah.

Kata kunci: Keberkesanan; penghalang nitrifikasi; stearin sawit; urea; urea diimpregnasi dengan biochar

\section{INTRODUCTION}

Low efficiency of nitrogen fertilizer applied to the agricultural crop is a common problem all around the world. In rice cultivation, the recovery of nitrogen $(\mathrm{N})$ is reported to be less than 50\% (Katyal et al. 1985; Singh et al. 2001). In Asia, average $\mathrm{N}$ recovery of irrigated rice is about $30 \%$ (Dobermann \& Fairhurst 2000). The main reason for the low efficiency is that much of the $\mathrm{N}$ applied as soluble fertilizer is lost from the plant-soil system through various pathways such as nitrification- 
denitrification, mineralization-immobilization, ammonia volatilization, leaching and surface runoff (Mikkelsen et al. 1995; Yan et al. 2003; Zhu \& Chen 2002).

Controlled released fertilizer (CRF) is defined as fertilizers containing plant nutrient with delayed availability for plant uptake and use or has longer nutrient availability to the plant than common fertilizer such as urea and ammonium nitrate (AAPFCO 1995). The principal process of CRF production is by covering or encapsulating conventional fertilizer such as urea with protective coating to control water penetration and dissolution rate of fertilizer (Trenkel 2010). The release pattern of CRF is affected by several factors such temperature, moisture content and osmotic potential (Carson \& Ozores-Hampton 2013; Carson et al. 2013; Morgan et al. 2009), but the release mechanism is difficult to comprehend as it also depends on numerous factors such as nature of the coating material, the type of CRF and agronomic conditions (Azeem et al. 2014; Carson \& Ozores-Hampton 2013).

Application of CRF has been well appraised for its various advantages. Specifically, it improves nutrient use efficiency, which will generally result in reduced loss of nutrients from crop fields. The application of CRF also reduces fertilizer toxicity to the plant especially for seedlings (Trenkel 2010). In the environmental perspective, CRF can reduce both nitrous oxide emission (Chu et al. 2004) and disturbance to aquatic and terrestrial ecosystem, as well as the atmosphere (Dalton \& Brand-Hardy 2003). The use of controlled release fertilizers may minimize various health risks related to fertilizer application especially N (Galloway \& Cowling 2002).

Biochar-impregnated urea and palm stearin coated urea are among the CRF products that are currently being developed for the agricultural market. Biocharimpregnated urea is a new fertilizer, which is intended to integrate biochar with urea into a fertilizer. It is produced by chemically reacting molten urea with biochar. The quantity of added biochar ranges between 5 and $10 \%$. The biochar used is originally obtained from rubber wood sawdust, which is pyrolysed at 300 and $700^{\circ} \mathrm{C}$. The negative surface charges from functional group of biochar such as carboxylic acid, phenolic and lactone improve the adsorption of positively charged ion from fertilizer (Dimin et al. 2014), potentially reducing nutrient loss from fertilizer application.

Palm stearin, a byproduct of palm oil production, can be used as a coating material for plain urea. This concept is adopted from Trenkel (2010) in which fertilizer coating is made of materials that release the nutrients through physical barriers. Palm stearin act as a physical barrier to the urea granules, preventing it from rapid dissolution upon making contact with water. Apart from palm stearin as physical barrier, nitrification inhibitors can be added to the urea coating to further enhance the performance of the CRFs.

Nitrification inhibitor such as 3,4-dimethylpyrazole phosphate (DMPP) has been utilized as a substance to enhance nitrogen use efficiency by reducing nitrification process with proven effectiveness in agriculture (Gong et al. 2012). Copper ( $\mathrm{Cu}$ ) and zinc ( $\mathrm{Zn})$ also has been studied as nitrification inhibitors. $\mathrm{Cu}$ reacts by binding to cell membranes and enzymes of nitrifying bacteria, disrupting the cell structure (Sato et al. 1988), while $\mathrm{Zn}$ is responsible for the disturbances of mitochondrial function. In this study, palm stearin was used as a base material to coat urea to produce controlled release fertilizer. The objective was to evaluate the effects of selected CRFs on growth, yield production and $\mathrm{N}$ uptake of Malaysian rice cultivar MR 220 CL1 under field condition.

\section{MATERIALS AND METHODS}

\section{EXPERIMENTAL SITE}

Field experiment was conducted at a rice field in Sungai Besar, in the State of Selangor, Malaysia $\left(3^{\circ} 42^{\prime} 20^{\prime \prime} \mathrm{N}\right.$, $\left.100^{\circ} 58^{\prime} 08^{\prime \prime} \mathrm{E}\right)$. Rice variety MR 220 CL1 was used as the planting material. The soil at the field was Selangor soil series (isohyperthermic, aeric tropic fluvaquent) (DOA 1993). The properties of the soil are presented in Table 1. Physico-chemical analyses of the soil were conducted. Mechanical analysis of the soil was performed using the pipette method and textural class was determined using United State Department of Agriculture (USDA) soil textural triangle. Soil $\mathrm{pH}$ was analyzed using Mettler Toledo $\mathrm{pH}$ meter in 1:2.5 soil to water ratio. Cation exchange capacity (CEC) was determined using leaching method (Chapman 1965). Total $\mathrm{N}$ was determined using Kjeldahl method with salicylic acid (Bremner \& Mulvaney 1982). Available phosphorus (P) was determined using Bray 2 method (Bray \& Kurtz 1945). Available copper (Cu), iron (Fe), manganese $(\mathrm{Mn})$ and zinc $(\mathrm{Zn})$ were determined using Mehlich 1 method (Mehlich 1953). Rice seedlings were grown in $3 \mathrm{~m} \times 3 \mathrm{~m}$ experimental plots. Soil around the plot was elevated to act as barrier. The seed rate was 100 $\mathrm{kg} \mathrm{ha}^{-1}$ and directly seeded into the plot.

\section{FERTILIZER APPLICATION AND SOIL SAMPLING}

Detailed properties of the CRFs used in this study are shown in Table 2. The CRFs were applied at the recommended rate of $120 \mathrm{~kg} \mathrm{~N} \mathrm{ha}^{-1}$ with three split applications at 15,35 and 55 days after seeding (DAS). Soil sampling was conducted seven days after each split application and during harvest to determine residual $\mathrm{N}$ status in the soil. Phosphorus $(\mathrm{P})$ in the form of triple superphosphate and potassium (K) in the form of muriate of potash fertilizer were applied as basal fertilizer at the rate of $50 \mathrm{~kg} \mathrm{P}_{2} \mathrm{O}_{5} \mathrm{ha}^{-1}$ and $50 \mathrm{~kg}$ $\mathrm{K}_{2} \mathrm{O}$ ha $^{-1}$, respectively. Standard agronomic practices were carried out to control insects, pests, diseases and weeds. Water level was maintained at 5-10 cm depth.

\section{PLANT PARAMETERS}

Indirect leaf chlorophyll index measurements were carried out with soil plant analysis development (SPAD) meter (Minolta SPAD-502, Konica Minolta, Japan) on the youngest most developed leaves. The SPAD readings were 
TABLE 1. Basic physical and chemical properties of experimental soil at $0-20 \mathrm{~cm}$ depth

\begin{tabular}{lc}
\hline Particle size distribution & Values \\
\hline Clay $(\%)$ & 64.06 \\
Silt $(\%)$ & 34.54 \\
Sand $(\%)$ & 1.33 \\
USDA textural class: Clay & \\
\hline Chemical properties & \\
\hline $\mathrm{pH}_{\mathrm{w}}(1: 2.5)$ & 6.04 \\
$\mathrm{CEC}(\mathrm{cmol} / \mathrm{kg})$ & 20.20 \\
Total $\mathrm{N}(\%)$ & 0.15 \\
Inorganic $\mathrm{NH}{ }_{4}^{+}-\mathrm{N}(\mathrm{mg} / \mathrm{kg})$ & 17.85 \\
Available $\mathrm{P}(\mathrm{mg} / \mathrm{kg})$ & 8.54 \\
Available $\mathrm{Cu}(\mathrm{mg} / \mathrm{kg})$ & 1.35 \\
Available $\mathrm{Fe}(\mathrm{mg} / \mathrm{kg})$ & 23.72 \\
Available $\mathrm{Mn}(\mathrm{mg} / \mathrm{kg})$ & 2.70 \\
Available $\mathrm{Zn}(\mathrm{mg} / \mathrm{kg})$ & 1.50 \\
\hline
\end{tabular}

TABLE 2. Fertilizers used to supply $\mathrm{N}$ and treatment properties

\begin{tabular}{|c|c|c|c|}
\hline $\mathrm{N}$ treatments & Code name & $\% \mathrm{~N}$ & Properties \\
\hline Urea (control) & Urea & 46 & $\begin{array}{l}\text { Granules } \\
\text { Agrenas }{ }^{\circledR}, \text { no coating }\end{array}$ \\
\hline $\begin{array}{l}\text { Biochar Impregnated Urea } \\
\text { (BIU) 300-5 }\end{array}$ & BIU 300-5 & 44 & $\begin{array}{l}\text { Powder } \\
\text { Urea added with } 5 \% \text { biochar pyrolysed at } 300^{\circ} \mathrm{C}\end{array}$ \\
\hline BIU 300-10 & BIU 300-10 & 43 & $\begin{array}{l}\text { Powder } \\
\text { Urea added with } 10 \% \text { biochar pyrolysed at } 300^{\circ} \mathrm{C}\end{array}$ \\
\hline BIU 700-5 & BIU 700-5 & 44 & $\begin{array}{l}\text { Powder } \\
\text { Urea added with } 5 \% \text { biochar pyrolysed at } 700^{\circ} \mathrm{C}\end{array}$ \\
\hline BIU 700-10 & BIU 700-10 & 42 & $\begin{array}{l}\text { Powder } \\
\text { Urea added with } 10 \% \text { biochar pyrolysed at } 700^{\circ} \mathrm{C}\end{array}$ \\
\hline Urea (Palm Stearin coated only) & PS & 41 & $\begin{array}{l}\text { Granules } \\
\text { Palm stearin as coating materials }\end{array}$ \\
\hline $\begin{array}{l}\text { Urea + DMPP } 100 \% \\
(0.464 \mathrm{~g} / 100 \mathrm{~g} \text { urea }) \\
\text { *recommended rate }\end{array}$ & PS+DMPP-100 & 41 & $\begin{array}{l}\text { Granules } \\
\text { Palm stearin compound added with DMPP }(0.464 \mathrm{~g} / 100 \mathrm{~g} \\
\text { urea) before coating with urea }\end{array}$ \\
\hline $\begin{array}{l}\text { Urea + DMPP } 50 \% \\
(0.232 \mathrm{~g} / 100 \mathrm{~g} \text { urea })\end{array}$ & PS+DMPP-50 & 42 & $\begin{array}{l}\text { Granules } \\
\text { Palm stearin compound added with DMPP }(0.232 \mathrm{~g} / 100 \mathrm{~g} \\
\text { urea) before coating with urea }\end{array}$ \\
\hline $\begin{array}{l}\text { Urea + DMPP } 150 \% \\
(0.696 \mathrm{~g} / 100 \mathrm{~g} \text { urea })\end{array}$ & PS+DMPP-150 & 39 & $\begin{array}{l}\text { Granules } \\
\text { Palm stearin compound added with DMPP }(0.696 \mathrm{~g} / 100 \mathrm{~g} \\
\text { urea) before coating with urea }\end{array}$ \\
\hline Urea $+\mathrm{Cu}$ & $\mathrm{PS}+\mathrm{Cu}$ & 40 & $\begin{array}{l}\text { Granules } \\
\text { Palm stearin compound added with } \mathrm{Cu}(5 \mathrm{~kg} / \mathrm{ha}) \text { before } \\
\text { coating with urea }\end{array}$ \\
\hline Urea $+\mathrm{Zn}$ & $P S+Z n$ & 40 & $\begin{array}{l}\text { Granules } \\
\text { Palm stearin compound added with } \mathrm{Zn}(10 \mathrm{~kg} / \mathrm{ha}) \text { before } \\
\text { coating with urea }\end{array}$ \\
\hline
\end{tabular}

taken at the middle of each leaf and averaged. Plant height (cm) was recorded at maturity (week 16). The plants were harvested on week 16 after seeding by cutting off the parts about $2 \mathrm{~cm}$ above soil surface. Harvested plants were dried at $60^{\circ} \mathrm{C}$ for $72 \mathrm{~h}$, separated into straw and grains. Dry matter yield of each part was recorded and Harvest index (HI) calculated as follows (1):

$\mathrm{HI}=($ Grain yield $/($ Grain yield + Biomass $)] \times 100$. 
Plant tissues were ground using a mechanical grinder. Total tissue $\mathrm{N}$ was analyzed using TruMac ${ }^{\circledR}$ CNS Analyzer. Total $\mathrm{N}$ uptake was calculated by multiplying total N (\%) with dry matter weight (Panda et al. 1995).

\section{STATISTICAL ANALYSIS}

Data were subjected to one-way ANOVA, and significant differences in means between the treatments were compared by Duncan's multiple range tests procedure at $p \leq 0.05$ with the Statistical Analysis System (SAS) software (version 9.4).

\section{RESULTS AND DISCUSSION}

\section{PLANT HEIGHT}

All CRF treatments showed significantly higher rice plant height compared to common urea (Table 3). The highest plant height $(116.9 \mathrm{~cm})$ was recorded in treatment BIU $700-5$ while the lowest value $(108.5 \mathrm{~cm})$ was observed in treatment that received common urea dosage. Generally, in grain crops, $\mathrm{N}$ improves the protein content in plant (Uchida 2000). When plants absorb sufficient amount of $\mathrm{N}$, protein will be available at an optimum level to accomplish metabolic processes, which in turn will improve the vegetative and reproductive growth of the plant, as well as improve the yield (Lawlor 2002). Improved growth could be attributed to higher plant height. Study by Fazlina et al. (2014) using sulfur coated urea also showed similar trend with rice that received coated urea dosage establishing higher plants height than that treated with common urea.

\section{LEAF CHLOROPHYLL CONTENT (SPAD READINGS)}

The results of plant chlorophyll content index (Minolta SPAD-502 values) for different treatments are presented in Table 3. SPAD reading for rice plants were significantly higher in CRF treatments compared to common urea. Measurement of leaf chlorophyll concentration is an important parameter that is frequently used to gauge general plant health in terms of its photosynthetic capacity and leaf $\mathrm{N}$ content.

In this study, SPAD readings for rice plants were significantly higher in seven CRF treatments, while that of three CRFS (BIU 700-5, PS and PS+DMPP-150) were not significantly different from common urea. Study by Loh et al. (2002) showed that SPAD reading was linearly correlated with chlorophyll content and $\mathrm{N}$ concentration in plants. Higher SPAD reading means higher chlorophyll content as a result of better $\mathrm{N}$ uptake. Higher $\mathrm{N}$ uptake by plant will increase the photosynthesis rate, subsequently improving plant growth. Higher $\mathrm{N}$ in plant also increases the amount of $\mathrm{N}$ per unit leaf area, as well as the amount of soluble protein (Evans 1989) which subsequently enhance plant photosynthesis.

According to Dobermann and Fairhurst (2000), the optimum SPAD threshold of wet seeding rice is between 29 and 32. From this study, application of CRFs has increased the SPAD reading for rice plant above the optimum SPAD threshold with values ranging at 35.2-37.5. The control treatment with urea only gave SPAD reading at 30.4 , which falls within the optimum threshold range. Increase in SPAD reading means CRF application improved $\mathrm{N}$ concentration in plants, as the result of more efficient $\mathrm{N}$ uptake by rice.

\section{GRAIN YIELD}

Data presented in Table 3 shows that plant grain yield was affected by CRF treatments. In economic aspect, grain yield is the most important parameter in CRF production, with the purpose of increasing the grain yield. All CRF treatments applied in this study increase the grain yield of rice, with seven CRFs showing significant increment (Table 3). Significant increase of grain yield recorded by BIU 300-10, 700-5, 700-10, PS+DMPP-100, PS+DMPP-50, PS+DMPP $150 \%$ and PS+Cu. PS+DMPP-50 displayed the highest increment among treatments. In term of percentage, the yield increment ranged from 4.5 to $13.6 \%$.

The BIU treatments (BIU 300-10, BIU 700-5 and BIU 700-10) showed significant increase in yield compared

TABLE 3. Rice growth parameters in response to the different CRFs application

\begin{tabular}{|c|c|c|c|c|}
\hline $\mathrm{N}$ treatments & $\begin{array}{c}\text { Plant height } \\
(\mathrm{cm})\end{array}$ & $\begin{array}{c}\text { SPAD } \\
\text { values }\end{array}$ & $\begin{array}{c}1000 \text { grain } \\
(\mathrm{g})\end{array}$ & $\begin{array}{c}\text { Grain yield } \\
\left(\mathrm{t} \mathrm{ha}^{-1}\right)\end{array}$ \\
\hline Urea & $108.5 \mathrm{~d}$ & $30.44 \mathrm{~b}$ & $25.73 b$ & $5.65 \mathrm{c}$ \\
\hline BIU 300-5 & $114.5 \mathrm{bc}$ & $36.89 \mathrm{a}$ & $26.19 \mathrm{ab}$ & $6.00 \mathrm{bc}$ \\
\hline BIU 300-10 & $114.3 \mathrm{bc}$ & $36.69 \mathrm{a}$ & $26.35 \mathrm{a}$ & $6.28 \mathrm{ab}$ \\
\hline BIU 700-5 & $116.9 \mathrm{a}$ & $34.35 \mathrm{ab}$ & $26.39 \mathrm{a}$ & $6.39 \mathrm{a}$ \\
\hline BIU 700-10 & $112.9 \mathrm{bc}$ & $36.84 \mathrm{a}$ & $26.05 \mathrm{ab}$ & $6.36 \mathrm{a}$ \\
\hline PS & $115.4 \mathrm{ab}$ & $35.19 \mathrm{ab}$ & $26.39 \mathrm{a}$ & $5.97 \mathrm{bc}$ \\
\hline PS+DMPP-100 & $112.2 \mathrm{c}$ & $36.43 \mathrm{a}$ & $26.27 \mathrm{ab}$ & $6.38 \mathrm{a}$ \\
\hline PS+DMPP-50 & $113.2 \mathrm{bc}$ & $37.40 \mathrm{a}$ & $26.37 \mathrm{a}$ & $6.42 \mathrm{a}$ \\
\hline PS+DMPP-150 & $114.9 \mathrm{bc}$ & $35.97 \mathrm{ab}$ & $26.22 \mathrm{ab}$ & $6.28 \mathrm{ab}$ \\
\hline $\mathrm{PS}+\mathrm{Cu}$ & $112.9 \mathrm{bc}$ & $37.15 \mathrm{a}$ & $26.40 \mathrm{a}$ & $6.16 \mathrm{ab}$ \\
\hline $\mathrm{PS}+\mathrm{Zn}$ & $114.0 \mathrm{bc}$ & $37.53 \mathrm{a}$ & $25.92 \mathrm{ab}$ & $5.91 \mathrm{bc}$ \\
\hline
\end{tabular}

Means in a column followed by common letter are not significantly different at $5 \%$ level using DMRT 
to urea, except for BIU 300-5. Biochar is a beneficial substance widely recognized for its various benefits such as improving soil physical properties (Atkinson et al. 2010; Downie et al.2009) and provides microbial habitat (Atkinson et al. 2010). More importantly, biochar is also capable of improving cation exchange capacity (CEC) and anion exchange capacity (AEC) in soil, consequently improving nutrient retention ability for better plant consumption (Sohi et al. 2010). With all these benefits, it will provide a conducive environment for plants to grow better and produce higher grain yield.

The use of palm stearin as a coating material appears to improve grain yield albeit not significantly. However, with the addition of nitrification inhibitors, rice yield was significantly increased. DMPP addition at 50, 100 and $150 \%$ rates all increased the yield significantly, as well as $\mathrm{Cu}$ addition. The use of DMPP in CRF was widely studied on various crops, resulting in significant yield increment. Heavy metal elements also have been studied as nitrification inhibitors previously with positive effects on reducing nitrification (Rovita \& Killorn 2008). Yield increment in $\mathrm{PS}+\mathrm{Cu}$ could be attributed to lower nitrification in soil, which enhances $\mathrm{N}$ use efficiency by rice. Treatment PS $+\mathrm{Zn}$ did not significantly improve yield probably due to the high level $\left(1.5 \mathrm{mg} \mathrm{kg}^{-1}\right)$ of $\mathrm{Zn}$ in soil (Table 1). The critical level of $\mathrm{Zn}$ in soil for rice is $1.0 \mathrm{mg} \mathrm{kg}^{-1}$ (Dobermann \& Fairhurst 2000). Therefore, all the treatments received the same effects of $\mathrm{Zn}$ inhibition in soil and the additional $\mathrm{Zn}$ in PS+Zn did not show significant effect.

\section{0-GRAIN WEIGHT}

1000-grain weight is an important indicator for rice quality. Higher 1000-grains weight means better grain quality. Generally, CRF application as a source of $\mathrm{N}$ improves grain quality. Six CRFs (BIU 300-10, BIU 700-5, PS+DMPP-100,
PS+DMPP-50, PS+Zn and PS) showed significantly higher 1000-grain weight than the other treatments (Table 3 ). Better $\mathrm{N}$ use efficiency and better $\mathrm{N}$ uptake by plants increase protein percentage in grain, resulting in higher mass per unit of grain (Chaturvedi 2005). In rice, nitrogen plays an important role in formation of organs and physiological processes, as well as becoming a major component in tillers and grains production (MARDI 2003), which explains the higher 1000-grain weight of rice with better $\mathrm{N}$ uptake.

\section{HARVEST INDEX}

Harvest index (HI) is the ratio of dry grain to the total aboveground dry matter weight (Mae et al. 2006). Higher $\mathrm{HI}$ means more of the harvested aboveground part of rice were grains. Since grain yield is the most important part of rice cultivation, better HI is preferred when CRF is applied to the rice field. From Figure 1, all the CRF treatments improved rice HI significantly, except for PS and PS+DMPP-150, which still showed improvement although insignificantly.

According to Hashim et al. (2015), total $\mathrm{N}$ uptake rice plant peaked during 11th week in which the rice is at grain formation stage. After 11th week, during grain filling and maturation stage, large portion of $\mathrm{N}$ required in rice come from the culm, leaves and panicles rather than directly from the soil (Jones et al.2011). It means, N uptake from soil was very minimal. This could probably be a major factor that improves HI. When plants absorb more $\mathrm{N}$ before the 11th week, more $\mathrm{N}$ will probably be transferred to grain, increasing HI or grain proportion over rice biomass. The period from planting up until the 11 th week is a crucial period in which rice need to absorb $\mathrm{N}$ in optimum amount. The ability of CRFs to increase $\mathrm{N}$ uptake by rice could give an advantage when rice plants were

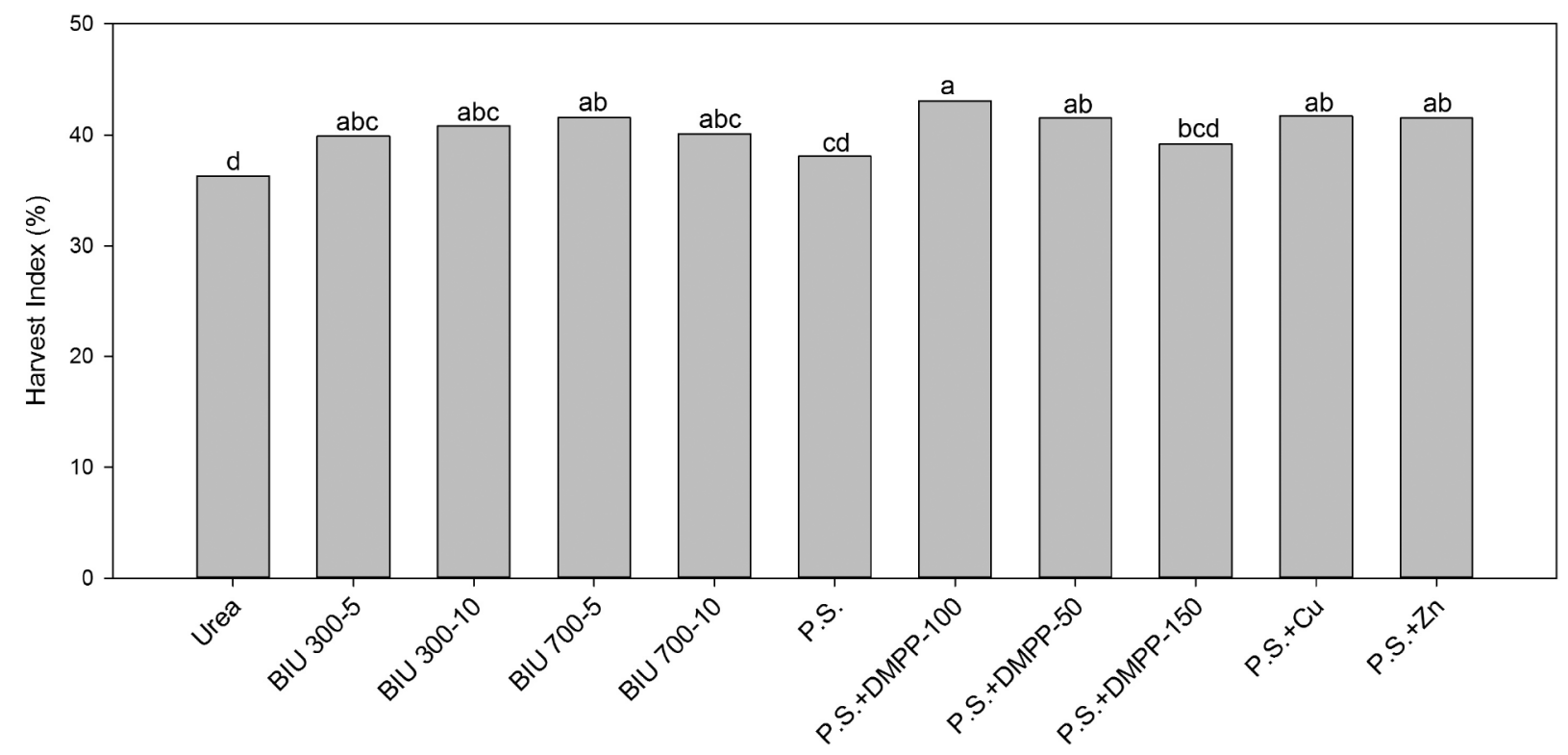

FIGURE 1. Harvest index of rice as affected by CRF application 
treated with it. Higher $\mathrm{N}$ uptake from CRFs application will promote higher $\mathrm{N}$ accumulation in rice tissue, which will eventually be transferred to the grain resulting in improved grain development and higher HI.

Addition of PS as coating without inhibitor probably did not reduce the loss of $\mathrm{N}$ especially in early period after application. Without inhibitory effects from nitrification inhibitors, $\mathrm{N}$ is more susceptible to losses. Therefore, it will reduce the availability of $\mathrm{N}$ in soil and rice plant could not remove higher $\mathrm{N}$ for its grain development. As for PS+DMPP-150, the increased rate of DMPP than the recommended rate of $0.464 \mathrm{~g} / 100 \mathrm{~g}$ urea might induced higher losses of $\mathrm{N}$ in the form ammonia $\left(\mathrm{NH}_{3}\right)$. The inhibitory effects of DMPP resulted in excessive $\mathrm{NH}_{4}{ }^{+} \mathrm{N}$ ions accumulation in soil upon urea application to the soil. Loosely water-bound $\mathrm{NH}_{4}{ }^{+} \mathrm{N}$ ions in the flooded soils might escape in the gaseous form of $\mathrm{NH}_{3}$ (Ghosh \& Bhat 1998).

\section{PLANT NITROGEN UPTAKE FROM CRFS APPLICATION}

Generally, application of CRFs increased nitrogen uptake in both rice grain and straw, although some of the increments were not significant (Table 4). In grain, the seven treatments that exhibited significant $\mathrm{N}$ uptake increment were BIU 30010, BIU 700-5, BIU 700-10, PS+DMPP-100, PS+DMPP-50, PS+DMPP-150 and PS+Cu. In the straw, only BIU 300-5 and BIU 300-10 exhibited significant increment. Again, this could probably be as a result of $\mathrm{N}$ translocation from vegetative parts of rice to the grain during the later stage of plant development (Jones et al. 2011).

CRF has the ability to gradually release its nutrient content to precisely match with the plant requirement (Hanafi et al. 2000). By using CRF, N could be supplied according to the plant development stages (Sharma 1979), allowing better $\mathrm{N}$ uptake by rice plant. Better $\mathrm{N}$ uptake from CRFs has also been proven in previous studies such as Kiran et al. (2010) and Fazlina et al . (2014) on rice and Nasima et al. (2011) on Guinea grass.

\section{RESIDUAL AMMONIUM $\left(\mathrm{NH}_{4}^{+}-\mathrm{N}\right)$ IN SOIL}

No significant differences were found among the treatments, including all the CRFs used for residual $\mathrm{N}$ in soil after harvesting (Figure 2). Residual $\mathrm{NH}_{4}{ }^{+} \mathrm{N}$ in soil during harvest ranged at $14.2-18.5 \mathrm{mg} \mathrm{kg}^{-1}$, which is almost equivalent to the $\mathrm{NH}_{4}^{+}-\mathrm{N}$ content of pre-planted soil (17.85 $\mathrm{mg} \mathrm{kg}^{-1}$ ) (Table 1). Most of the applied $\mathrm{N}$ from the fertilizers are either utilized by the rice or susceptible to loss to the environment. When fertilizer application precisely matched with crop needs, less residual $\mathrm{N}$ were traced in soil (Andraski et al. 2000), especially when the rate of application was equal. This trend is also similar to the study by Fazlina et al. (2014), where CRFs application on rice end up having less residual $\mathrm{N}$ in soil. When CRFs were applied to the soil, more efficient uptake by rice resulted in more $\mathrm{N}$ accumulated in rice.

Higher residual $\mathrm{N}$ in soil does not indicate greater fertilizer efficiency, as more removal of $\mathrm{N}$ by rice would result in less residual $\mathrm{N}$ in the soil. Therefore, a more tangible indicator of fertilizer performance is the actual $\mathrm{N}$ uptake in rice. In essence, higher $\mathrm{N}$ uptake by rice is indicative of better $\mathrm{N}$ use efficiency, which can serve as a bench mark to evaluate the performance of CRFs.

\section{CONCLUSION}

As a conclusion, the application of CRFs urea improved rice growth and production especially BIU 700-5, BIU 700-10, PS+DMPP-100 and PS+DMPP-50. Biochar and nitrification inhibitors incorporation with urea fertilizer in CRFs increased rice yield by 4 to $13 \%$, as well as improved plant height, chlorophyll content in leaf, grain quality and HI. The application of CRFs also improved rice $\mathrm{N}$ uptake, especially in grain by up to $36 \%$, but did not improve residual $\mathrm{N}$ in soil. The CRFs used in this study were newly developed with major improvement still needed to be made for better performance. High efficiency CRFs can reduce fertilizer application rounds and save labor cost without compromising crop yield.

TABLE 4. Nitrogen uptake by rice from different CRFs application

\begin{tabular}{lcccc}
\hline \multirow{2}{*}{ Treatment } & \multicolumn{2}{c}{ Grain } & \multicolumn{2}{c}{ Straw } \\
& Total N $(\%)$ & N Uptake $\left(\mathrm{kg} \mathrm{ha}^{-1}\right)$ & Total N $(\%)$ & N Uptake $\left(\mathrm{kg} \mathrm{ha}^{-1}\right)$ \\
\hline Urea & $1.42 \mathrm{a}$ & $75.72 \mathrm{c}$ & $0.83 \mathrm{c}$ & $80.36 \mathrm{~b}$ \\
BIU 300-5 & $1.46 \mathrm{a}$ & $87.65 \mathrm{abc}$ & $1.23 \mathrm{a}$ & $112.11 \mathrm{a}$ \\
BIU 300-10 & $1.56 \mathrm{a}$ & $97.73 \mathrm{ab}$ & $1.21 \mathrm{a}$ & $110.38 \mathrm{a}$ \\
BIU 700-5 & $1.61 \mathrm{a}$ & $102.67 \mathrm{a}$ & $1.16 \mathrm{ab}$ & $104.50 \mathrm{ab}$ \\
BIU 700-10 & $1.52 \mathrm{a}$ & $96.30 \mathrm{ab}$ & $0.99 \mathrm{abc}$ & $94.60 \mathrm{ab}$ \\
PS & $1.56 \mathrm{a}$ & $92.72 \mathrm{abc}$ & $1.15 \mathrm{ab}$ & $103.65 \mathrm{ab}$ \\
PS+DMPP-100 & $1.49 \mathrm{a}$ & $95.66 \mathrm{ab}$ & $0.87 \mathrm{bc}$ & $97.95 \mathrm{ab}$ \\
PS+DMPP-50 & $1.51 \mathrm{a}$ & $96.73 \mathrm{ab}$ & $1.00 \mathrm{abc}$ & $99.91 \mathrm{ab}$ \\
PS+DMPP-150 & $1.56 \mathrm{a}$ & $98.22 \mathrm{ab}$ & $1.12 \mathrm{abc}$ & $108.74 \mathrm{ab}$ \\
PS+Cu & $1.56 \mathrm{a}$ & $95.75 \mathrm{ab}$ & $1.14 \mathrm{ab}$ & $99.19 \mathrm{ab}$ \\
PS+Zn & $1.44 \mathrm{a}$ & $84.98 \mathrm{bc}$ & $1.18 \mathrm{ab}$ & $93.46 \mathrm{ab}$ \\
\hline
\end{tabular}

Means in a column followed by a common letter are not significantly different at $5 \%$ level using DMRT 


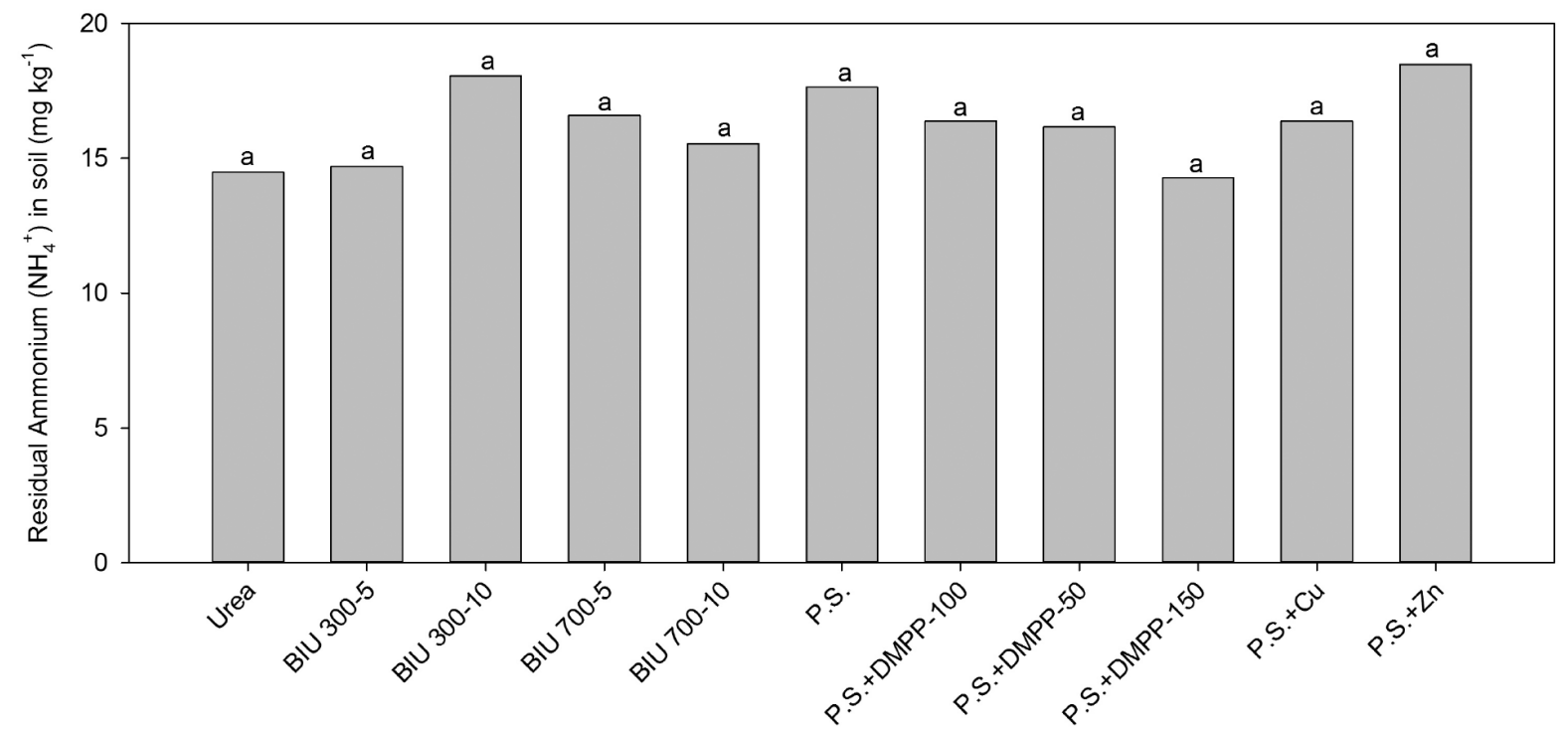

FIGURE 2. Residual of $\mathrm{NH}_{4}^{+}$in soil during rice harvesting as influenced by CRF application

\section{ACKNOWLEDGEMENTS}

Financial support for this study was received from LongTerm Research Grant Scheme (LRGS) from the Ministry of Higher Education, Malaysia under the project 'OneBAJA: The Next Generation Green and Economical Urea'. Special thanks to science officers at the Department of Land Management, Universiti Putra Malaysia (UPM), especially Mrs. Umi Kalthom Asmaon for expert work and guidance throughout the study, and to Dr. Alagie Bah for valuable helps in preparing this manuscript.

\section{REFERENCES}

Andraski, T.W., Bundy, L.G. \& Brye, K.R. 2000. Crop management and corn nitrogen rate effects on nitrate leaching. Journal of Environmental Quality 29: 1095-1103.

Association of American Plant Food Control Officials (AAPFCO). 1995. Official Publication No. 48. Indiana, USA: Association of American Plant Food Control Officials, Inc.

Atkinson, C.J., Fitzgerald, J.D. \& Hipps, N.A. 2010. Potential mechanisms for achieving agricultural benefits from biochar application to temperate soils: A review. Plant and Soil 337: $1-18$

Azeem, B., KuShaari, K., Man, Z.B., Basit, A. \& Thanh, T.H. 2014. Review on materials and methods to produce controlled release coated urea fertilizer. Journal of Controlled Release 181: 11-21.

Bray, R.H. \& Kurtz, L.T. 1945. Determination of total, organic, and available forms of phosphorus in soils. Soil Science 59: 39-45.

Bremner, J.M. \& Mulvaney, C.S. 1982. Total nitrogen. In Methods of Soil Analysis, edited by Page, A.L., Miller, R.H. \& Keeny, D.R. Madison. USA: American Society of Agronomy and Soil Science Society of America. pp. 1119-1123.

Carson, L.C., Ozores-Hampton, M. \& Morgan, K.T. 2013. Nitrogen release from controlled-release fertilizers in seepage-irrigated tomato production in South Florida. Proceedings of the Florida State Horticultural Society 126: 131-135.
Carson, L.C. \& Ozores-Hampton, M. 2013. Factors affecting nutrient availability, placement, rate, and application timing of controlled-release fertilizers for Florida vegetable production using seepage irrigation. HortTechnology 23: 553-562.

Chapman, H.D. 1965. Cation-exchange capacity. Agronomy Journal 9: 891-901.

Chaturvedi, I. 2005. Effect of nitrogen fertilizers on growth, yield and quality of hybrid rice (Oryza sativa). Journal of Central European Agriculture 6(4): 611-618.

Chu, H., Hosen, Y. \& Yagi, K. 2004. Nitrogen oxide emission and microbial activities in a Japanese Andisol as affected by $\mathrm{N}$-fertilizer management. Japanese Society of Soil Science and Plant Nutrition 50(2): 287-292.

Dalton, H. \& Brand-Hardy, R. 2003. Nitrogen: The essential public enemy. Journal of Applied Ecology 40: 771-781.

Department of Agriculture of Malaysia (DOA). 1993. Panduan Mengenali Siri-Siri Tanah Utama di Semenanjung Malaysia. Kuala Lumpur: Jabatan Pertanian Semenanjung Malaysia.

Dimin, M.F., Se, S.M., Azizah, S. \& Hashim, M.M. 2014. Urea impregnated biochar to minimize nutrients loss in paddy soils. International Journal of Automotive and Mechanical Engineering 10: 2016-2024.

Dobermann, A. \& Fairhurst, T.H. 2000. Rice: Nutrient Disorders and Nutrient Management. Los Banos, Philippines: International Rice Research Institute.

Downie,A., Crosky, A. \& Munroe, P. 2009. Physical properties of biochar. In Biochar for Environmental Management: Science and Technology, edited by Lehmann, J. \& Joseph, S. London: Earthscan. pp. 13-29.

Evans, J.R. 1989. Photosynthesis and nitrogen relationships in leaves of $\mathrm{C}_{3}$ plants. Oecologia 78: 9-19.

Fazlina, N.S., Khanif, Y.M. \& Oad, F.C. 2014. Nutrient uptake $\mathrm{pH}$ changes and yield of rice under slow release sulfur coated urea fertilizers. Australian Journal of Crop Science 8(10): 1359-1366.

Galloway, J.N. \& Cowling, E.B. 2002. Reactive nitrogen and the world: 200 years of change. AMBIO 31(2): 64-71.

Ghosh, B.C. \& Bhat, R. 1998. Environmental hazards of nitrogen loading in wetland rice fields. Environmental Pollution 102(1): 123-126. 
Gong, P., Zhang, L., Wu, Z. \& Li, D. 2012. Laboratory study of the effects of nitrification inhibitors on the abundance of ammonia-oxidizing bacteria and archaea in a Hap-Ustic Luvisol. African Journal of Microbiology Research 6(48): 7428-7434.

Hanafi, M.M., Eltaib, S.M. \& Ahmad, M.B. 2000. Physical and chemical characteristics of controlled release compound fertilizer. European Polymer Journal 36(10): 2081-2088.

Hashim, M.M., Khanif, Y.M., Radziah, O. \& Samsuri,A.W. 2015. Characterization of nitrogen uptake pattern in Malaysian rice MR219 at different growth stages using ${ }^{15} \mathrm{~N}$ Isotope. Rice Science 22(5): 250-254.

Jones, C., Olson-Rutz, K. \& Dinkins, C.P. 2011. Nutrient Uptake Timing by Crops. Montana, USA: Montana State University.

Katyal, J.C., Bijay-Singh, Vlek, P.L.G. \& Craswell, E.T. 1985. Fate and efficiency of nitrogen fertilizers applied to wetland rice: II. Punjab, India. Fertilizer Research 6: 279-290.

Kiran, J.K., Khanif, Y.M., Amminuddin, H. \& Anuar, A.R. 2010. Effects of controlled release urea on the yield and nitrogen nutrition of flooded rice. Communications in Soil Science and Plant Analysis 41(7): 811-819.

Lawlor, D.W. 2002. Carbon and nitrogen assimilation in relation to yield: Mechanisms are the key to understanding production systems. Journal of Experimental Botany 53: 773-787.

Loh, C.W.F., Grabosky, J.C. \& Bassuk, N.L. 2002. Using the SPAD 502 meter to access chlorophyll and nitrogen content of Benjamin fig and cottonwood leaves. HortTechnology 12(4): 682-686.

Mae, T., Inaba, A., Kaneta, Y., Masaki, S., Sasaki, M., Aizawa, M., Okawa, S., Hasegawa, S. \& Makino, A. 2006. A largegrain rice cultivar, Akita 63 , exhibits high yields with high physiological N-use efficiency. Field Crops Research 97(23): 227-237.

Malaysia Agricultural Research and Development Institute (MARDI). 2003. Varieti Padi MR220. Kuala Lumpur: Institut Penyelidikan dan Kemajuan Pertanian Malaysia.

Mehlich, A. 1953. Determination of $\mathrm{P}, \mathrm{Ca}, \mathrm{Mg}, \mathrm{K}, \mathrm{Na}$, and $\mathrm{NH}_{4}$. Raleigh, North Carolina: North Carolina Soil Test Division (Mimeo).

Mikkelsen, D.S., Jayaweera, G.R. \& Rolston, D.E. 1995. Nitrogen fertilization practices of lowland rice culture. In Nitrogen Fertilization in the Environment, edited by Bacon, P.E. Sydney: Marcel Dekker Inc. pp. 171-223.

Morgan, K.T., Cushman, K.E. \& Sato, S. 2009. Release mechanisms for slow- and controlled-release fertilizers and strategies for their use in vegetable production. HortTechnology 19: 10-12.

Nasima, J., Khanif, Y.M., Dharejo, K.A., Arifin, A. \& Hazandy, A.H. 2011. A field evaluation of coated urea with biodegradable materials and selected urease inhibitors. African Journal of Biotechnology 10(85): 19729-19736.
Panda, M.M., Mosier, A.R., Mohanty, S.K., Chakravorti, S.P., Chalam, A.B. \& Reddy, M.D. 1995. Nitrogen utilization by lowland rice as affected by fertilization with urea and green manure. Fertilizer Research 40(3): 215-223.

Rovita, D. \& Killorn, R. 2008. Heavy-metal inhibition of nitrification in selected Iowa soils treated with Stay-N 2000. Communications in Soil Science and Plant Analysis 39: 972-982.

Sato, C., Leung, S.W. \& Schnoor, J.L. 1988. Toxic response of Nitrosomonas europaea to copper in inorganic medium and wastewater. Water Research 22: 1117-1127.

Sharma, G.C. 1979. Controlled-release fertilizer and horticultural applications. Scientia Horticulturae 11(2): 107-129.

Singh, B., Bronson, K.F., Singh, Y. \& Pasuquin, E. 2001. Nitrogen-15 balance as affected by rice straw management in a rice-wheat rotation in northwest India. Nutrient Cycling in Agroecosystems 59: 227-237.

Sohi, S.P., Krull, E., Lopez-Capel, E. \& Bol, R. 2010. A review of biochar and its use and function in soil. Advances in Agronomy 105: 47-82.

Trenkel, M.E. 2010. Slow- and Controlled-Release and Stabilized Fertilizers: An Option for Enhancing Nutrient Use Efficiency in Agriculture. Paris, France: International Fertilizer Industry Association.

Uchida, R. 2000. Essential nutrient for plant growth: Nutrients function and deficiency symptoms. In Plant Nutrient Management in Hawaii's Soils, Approaches for Tropical and Subtropical Agriculture, edited by Silva, J.A. \& Uchida, R. Hawaii: University of Hawaii Press. pp. 31-55.

Yan, X.Y., Akimoto, H. \& Ohara, T. 2003. Estimation of nitrous oxide, nitric oxide and ammonia emissions from croplands in East, Southeast and South Asia. Global Change Biology 9: 1080-1096.

Zhu, Z.L. \& Chen, D.L. 2002. Nitrogen fertilizer use in China: Contributions to food production impacts on the environment and best management strategies. Nutrient Cycling in Agroecosystems 63: 117-127.

Department of Land Management, Faculty of Agriculture Universiti Putra Malaysia 43400 Serdang, Selangor Darul Ehsan Malaysia

*Corresponding author; email: muazhashim@gmail.com

Received: 24 November 2015

Accepted: 28 December 2016 